\title{
Activity-Dependent Regulation of $\mathrm{Na}^{+}, \mathrm{K}^{+}$-ATPase $\alpha$ Isoform mRNA Expression In Vivo
}

\author{
Marina Mata, Virginia Hieber, Michael Beaty, Michael Clevenger, and David J. Fink \\ Department of Neurology, University of Michigan; and GRECC, V. A. Medical Center, Ann Arbor, Michigan, U.S.A.
}

\begin{abstract}
To investigate the functional role of the different $\mathrm{Na}^{+}, \mathrm{K}^{+}$-ATPase $\alpha$ (catalytic) subunit isoforms in neuronal cells, we used quantitative in situ hybridization with riboprobes specific for $\alpha 1, \alpha 2$, and $\alpha 3$ isoforms to measure the level of $\alpha$ isoform-specific expression in the neuroendocrine cells of the supraoptic (SON) and paraventricular (PVN) nuclei of rat hypothalamus. A prolonged increase in electrical activity of these cells, achieved by 5 days of salt treatment, increased the amount of $\alpha 1$ isoform mRNA in the
\end{abstract}

SON and PVN by $50 \%$. Levels of $\alpha 1 \mathrm{mRNA}$ in other brain regions and levels of $\alpha 2$ and $\alpha 3$ mRNAs were not affected by salt treatment. We conclude that the $\alpha 1$ isoform $\mathrm{Na}^{+}, \mathrm{K}^{+}$-ATPase may be specifically adapted to pump out $\mathrm{Na}^{+}$, which enters the cells through voltage-gated channels during neuronal depolarization. Key Words: $\mathrm{Na}^{+}, \mathrm{K}^{+}$-ATPase-mRNA-Isoform-CNS. Mata M. et al. Activity-dependent regulation of $\mathrm{Na}^{+}, \mathrm{K}^{+}$-ATPase $\alpha$ isoform mRNA expression in vivo. $J$. Neurochem. 59, 622-626 (1992).
Three isoforms of the $\alpha$ (catalytic) subunit of the enzyme $\mathrm{Na}^{+}, \mathrm{K}^{+}$-ATPase are expressed in the nervous system (Sweadner, 1989). The products of three different genes (Lingrel et al., 1990), they demonstrate distinct regional and cellular distributions within the nervous system (Filuk et al., 1989; Hieber et al., 1991; Mata et al., 1991; Watts et al., 1991). Each of the $\alpha$ isoforms exchanges three $\mathrm{Na}^{+}$for two $\mathrm{K}^{+}$(Sweadner, 1985; Ratkowski et al., 1989; Goldshleger et al., 1990 ), and in rodents $\alpha 1$ has a lower affinity for inhibition by ouabain than $\alpha 2$ or $\alpha 3$ (Urayama and Nakao, 1979; Sweadner, 1985; Urayama and Sweadner, 1988; Feige et al., 1989). However, the reported $\mathrm{Na}^{+}$ affinity of the different isoforms varies widely (Skou, 1962; Urayama and Nakao, 1979; Sweadner, 1985; Feige et al., 1989; Brodsky and Guidotti, 1990; Jewell and Lingrel, 1991); this has limited interpretation of the functional significance of the existence of three isoforms in the nervous system.

In vitro, conditions that increase the activity of the $\mathrm{Na}^{+}, \mathrm{K}^{+}$-ATPase pump, such as hypokalemia or ionophore-mediated $\mathrm{Na}^{+}$influx, increase both the activity and the expression of pump subunits (Pollack et al., 1981; Bowen and McDonough, 1987; Pressley et al., 1988; Lescale-Matys et al., 1990). In the CNS in vivo, inhibition of $\mathrm{Na}^{+}$influx by intraventricular infusion of tetrodotoxin substantially reduces the functional transport capacity of $\mathrm{Na}^{+}, \mathrm{K}^{+}$-ATPase in brain, concomitant with a reduction in the number of $\mathrm{Na}^{+}, \mathrm{K}^{+}$-ATPase sites in brain measured by ouabain binding (Swann, 1991). One approach to investigate isoform-specific pump function, then, may be to measure changes in isoform expression in response to specific physiologic stimuli.

The oxytocin- and vasopressin-containing neuroendocrine cells of the supraoptic (SON) and paraventricular (PVN) nuclei provide an excellent model for such manipulation. Dehydration increases the rate of action potential firing in both types of neurons in those nuclei (Arnauld et al., 1975; Brimble and Dyball, 1977; Poulain et al., 1977), which correlates with increased metabolic activity in the posterior pituitary (Schwartz et al., 1979), due principally to activation of $\mathrm{Na}^{+}, \mathrm{K}^{+}$-ATPase in the nerve terminals of the vasopressin-containing neurons (Mata et al., 1980). The anatomic localization of cell bodies in discrete regions of the hypothalamus and exquisite physiologic control make this system ideal for investigations of activity-dependent regulation of gene expression.

We used quantitative in situ hybridization with ${ }^{35} \mathrm{~S}-$
Received November 5, 1991; revised manuscript received January 22, 1992; accepted January 31, 1992.

Address correspondence and reprint requests to Dr. D. J. Fink at GRECC, V. A. Medical Center, 2215 Fuller Road, Ann Arbor, MI 48105, U.S.A.
Abbreviations used: PVN, paraventricular nucleus; SON, supraoptic nucleus; SSC, saline-sodium citrate. 
labeled riboprobes specific for the $\alpha 1, \alpha 2$, and $\alpha 3$ isoforms of $\mathrm{Na}^{+}, \mathrm{K}^{+}$-ATPase to compare isoform-specific mRNA levels in the SON and PVN of normal and salt-treated rats. We anticipated that expression of those isoforms required to maintain low intracellu$\operatorname{lar} \mathrm{Na}^{+}$concentration in the face of depolarization-related $\mathrm{Na}^{+}$influx would be increased in the SON and PVN of the salt-treated rats. We found that the level of $\alpha 1$ isoform mRNA is specifically increased in the SON and PVN following salt treatment.

\section{MATERIALS AND METHODS}

\section{Materials}

Male Sprague-Dawley rats (weighing 200-250 g) were obtained from Harlan. ${ }^{35}$ S-Labeled UTP was obtained from Amersham. The remainder of the reagents were reagent or molecular biology grade as required.

\section{Salt treatment}

Salt-treated rats were given $2 \% \mathrm{NaCl}$ in water to drink for 5 days. We chose 5 days of salt treatment because it has been shown using extracellularly recorded action potentials that the mean firing rate of neurons in the SON of monkeys increases linearly over a 5-day period of water deprivation (Arnauld et al., 1975), and we had previously found that after 5 days of salt loading in the rat, glucose utilization in the posterior pituitary is dramatically increased as measured by $\left[{ }^{14} \mathrm{C}\right]$ deoxyglucose uptake (Schwartz et al., 1979). We did not examine $\mathrm{Na}^{+}, \mathrm{K}^{+}$-ATPase mRNA distribution at other time points. Control rats were allowed access to water ad libitum. The animals were killed by decapitation, and 10$\mu \mathrm{m}$-thick cryostat sections were cut for in situ hybridization.

\section{Preparation of riboprobes}

A 203-bp BamHI-PstI restriction fragment from the 3 untranslated region of $\alpha 1 \mathrm{cDNA}$ and a 342-bp PstI-EcoRI fragment containing a portion of the translated region of the $\alpha 3$ cDNA were subcloned in the vector pGEM4, and ${ }^{35} \mathrm{~S}$-labeled riboprobes were prepared as described (Hieber et al., 1991; Mata et al., 1991). A 200-bp probe to the untranslated $3^{\prime}$ region of $\alpha 2$ cDNA was prepared using polymerase chain reaction with 30-bp oligonucleotide primers (upstream position 3,521-3,551 and downstream position 3,750-3,780) to which the 17-bp sequences for SP6 and T7 promoters were attached before synthesis. The specificity of these riboprobes for individual $\alpha$ isoforms has been demonstrated (Hieber et al., 1991; Mata et al., 1991).

\section{In situ hybridization}

In situ hybridization was performed as described (Hieber et al., 1991; Mata et al., 1991). In brief, the cryostat-cut sections of brain were covered with an aliquot of hybridization buffer containing $\sim 5 \times 10^{4} \mathrm{cpm} / \mu \mathrm{l}$ of ${ }^{35} \mathrm{~S}$-labeled RNA probe and sealed with coverslips. Sections were hybridized for $21 \mathrm{~h}$ at $55^{\circ} \mathrm{C}$. After removal of the labeled probe, the sections were treated with $2 \times$ saline-sodium citrate (SSC) at room temperature for $10 \mathrm{~min}, 50 \%$ formamide in $2 \times$ SSC at $55^{\circ} \mathrm{C}$ for $30 \mathrm{~min}, 50 \mu \mathrm{g} / \mathrm{ml}$ of RNase $\mathrm{A}$ at $37^{\circ} \mathrm{C}$ for $30 \mathrm{~min}$, and $2 \times \mathrm{SSC}$ at room temperature for $30 \mathrm{~min}$. The slides were exposed to Kodak XAR film for 1-14 days, and selected slides were subsequently dipped in Kodak NTB-2 emulsion (diluted 1:1 with distilled water) and exposed at $4^{\circ} \mathrm{C}$. These latter slides were developed and counterstained with cresyl violet to allow the cellular localization of the silver grains to be assessed.

\section{Quantitative analysis}

In situ hybridization was carried out as described, and the amount of label (equivalent to nanoCuries per gram of tissue of ${ }^{14} \mathrm{C}$-labeled standards) in SON, PVN, cortex, and thalamus was determined using computerized densitometry (MCID; Imaging Resources, Inc.) and commercially available brain paste standards (Amersham). Each film was exposed long enough to allow the measured densities to all fall within the linear range of the film. The areas sampled included the entire area of each region visible in a section, and values were averaged for areas with several different densities, e.g., cortex. The statistical significance of the differences was determined using Kruskal-Wallis one-way analysis of variance (Wilkinson, 1986).

\section{RESULTS}

In untreated control rats, $\alpha 1, \alpha 2$, and $\alpha 3$ mRNAs had distinct and characteristic regional distributions in the brain, as reported previously (Filuk et al., 1989; Hieber et al., 1991; Watts et al., 1991). The $\alpha 1, \alpha 2$, and $\alpha 3$ isoform mRNAs were all found in the SON and in the PVN (Fig. 1, top row). This agrees with immunocytochemical evidence for the presence of all three $\alpha$ isoforms in the posterior pituitary, where the axon terminals are found (Rowe et al., 1991). After 5 days of salt treatment, the amount of $\alpha 1$ mRNA in the SON and in the PVN increased substantially (Fig. 1 , bottom row). The increase was apparent both in absolute terms and in relation to the amount of $\alpha 1$ mRNA in other regions of brain, which were not altered by treatment. In contrast to the increase in $\alpha 1$ mRNA content, $\alpha 2$ and $\alpha 3$ mRNA levels in the SON and PVN and in other regions of brain were not affected by salt treatment.

Light microscopic examination of the same section exposed to emulsion for 12 days and stained with cresyl violet demonstrated that the $\alpha 1 \mathrm{mRNA}$ was found predominantly over neuronal nuclei in the SON and the PVN (Fig. 2). The method used does not allow simultaneous determination of levels of all three isoform mRNAs in individual identified neurons. However, all three isoform mRNAs were found throughout the SON and PVN.

Quantitative analysis of the regional distribution of radioactivity was carried out using computerized densitometry of the autoradiograph. The amount of $\alpha 1$ isoform mRNA in the cortex and thalamus was unchanged by the salt treatment, whereas the amount of $\alpha 1 \mathrm{mRNA}$ in the PVN and in the SON was increased by $50 \%$ above control values (Fig. 3). The amounts of $\alpha 2$ and $\alpha 3$ mRNAs were not significantly changed by salt treatment in any of the brain regions examined quantitatively (Table 1).

\section{DISCUSSION}

When the several $\alpha$ isoforms were initially identified in brain, it was suggested that different isoforms 

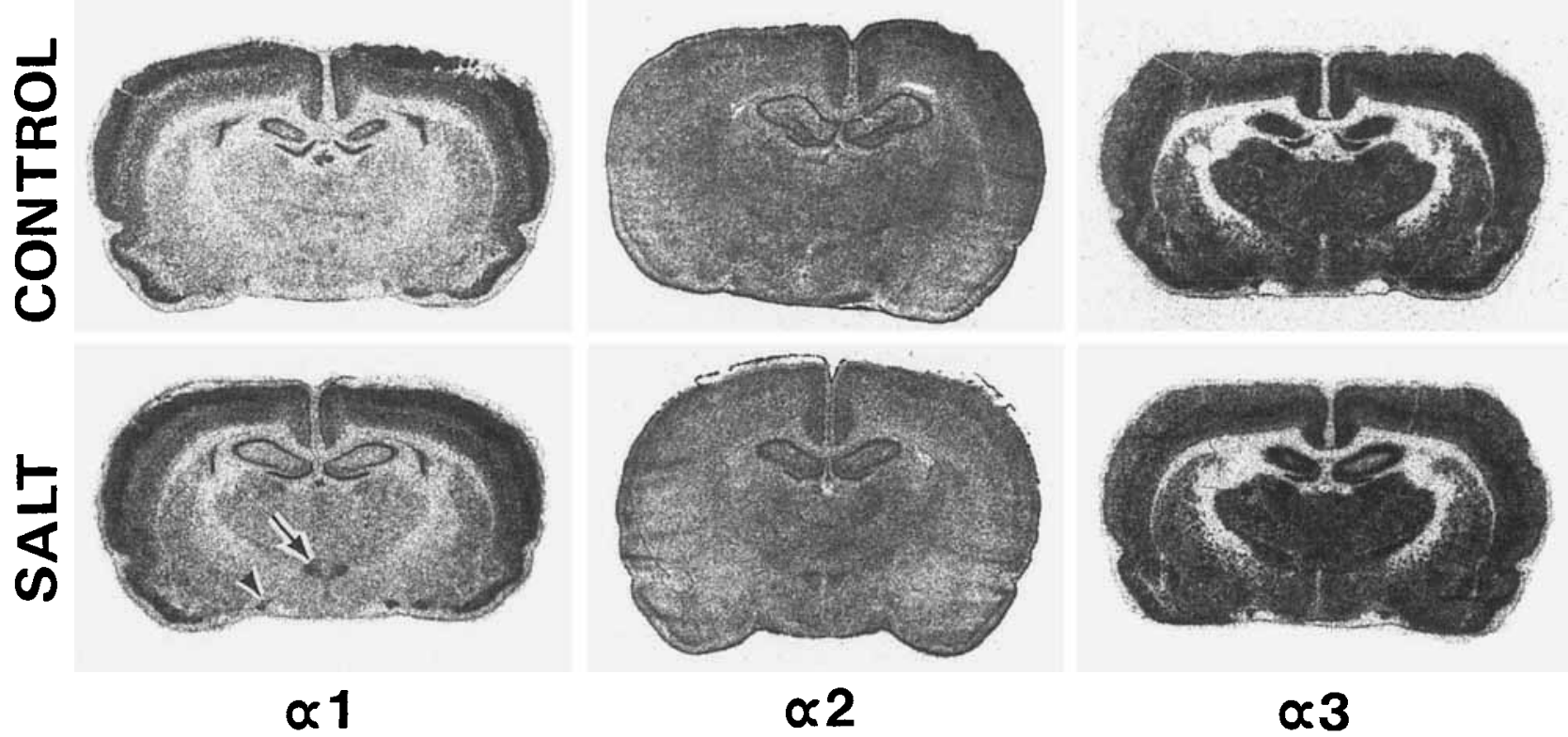

$\alpha 2$

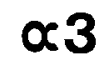

FIG. 1. Autoradiographs of in situ hybridization with ${ }^{35} \mathrm{~S}$-labeled riboprobes specific for $\alpha 1, \alpha 2$, and $\alpha 3$ isoforms of $\mathrm{Na}^{+}, \mathrm{K}^{+}$-ATPase. The SON (arrowhead) and PVN (arrow) show increased $\alpha 1$ mRNA levels in the salt-treated (bottom row) compared with control (top row) animals. Expression of $\alpha 1$ in other regions of brain appears unchanged. The experiment was repeated twice, first with three rats in each group and then with five rats in each group. Both experiments produced similar results. Using this method, the amount of hybridization can be compared between different regions of brain or between different animals using the same probe. However, quantitative comparison between the different probes cannot be performed because the specific activity and specific binding characteristics of each probe to its mRNA are not known.

might represent neuron- and glia-specific forms of the enzyme (Specht and Sweadner, 1984; Sweadner, 1985). Subsequent work has clearly shown that each of the isoforms is found in neurons in different regions of the brain at the mRNA (Filuk et al., 1989; Hieber et al., 1991; Mata et al., 1991; Watts et al., 1991) and protein (McGrail and Sweadner, 1986; McGrail et al., 1991) levels and that more than one $\alpha$

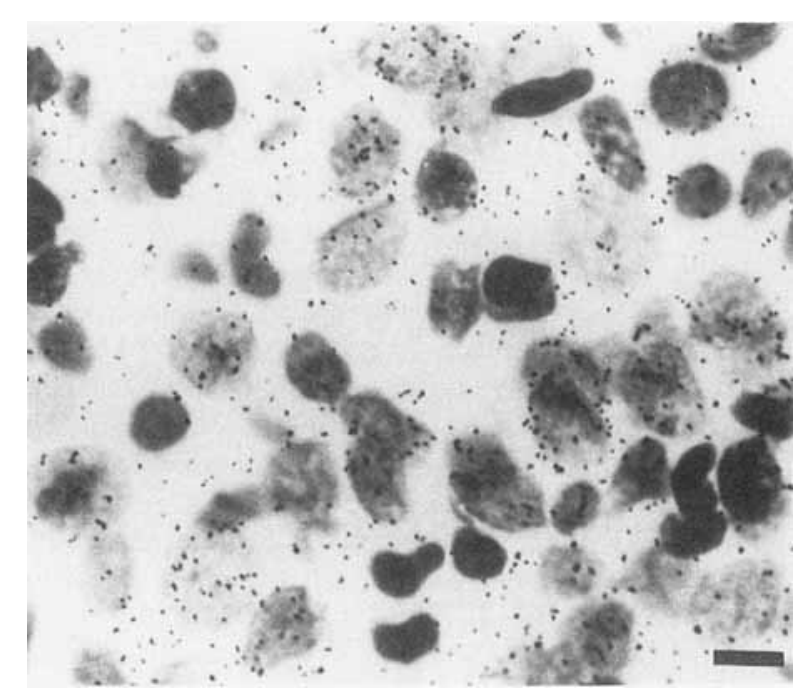

FIG. 2. Light micrograph of in situ hybridization for $\alpha 1$ mRNA in the PVN of a salt-treated animal shows silver grains over nuclei of most neuronal and some glial cells. Bar $=10 \mu \mathrm{m}$. isoform may be found in an individual neuron (Mata et al., 1991).

The functional role of different isoforms in neurons has not been established. All three $\alpha$ isoforms exchange three $\mathrm{Na}^{+}$for two $\mathrm{K}^{+}$(Sweadner, 1985; Ratkowski et al., 1989; Goldshleger et al., 1990). On the one hand, several studies have shown that $\mathrm{Na}^{+}, \mathrm{K}^{+}$-ATPase in membrane fractions isolated from brain (presumably $\alpha 2$ and/or $\alpha 3$ isoforms) has a higher affinity for $\mathrm{Na}^{+}$than does $\alpha 1$ isoform isolated from kidney (Skou, 1962; Urayama and Nakao, 1979; Sweadner, 1985). In addition, rat $\alpha 1$ isoform

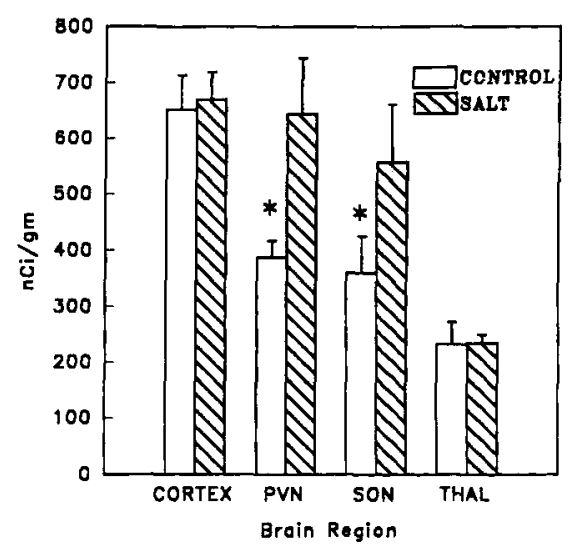

FIG. 3. Quantitative comparison of $\alpha 1$ mRNA levels in specific brain regions. Data are mean \pm SD (bars) values. ${ }^{*} p<0.01$ by Kruskal-Wallis one-way analysis of variance. 
TABLE 1. Quantitative comparison of $\alpha 2$ and $\alpha 3$ mRNAs in brain regions

\begin{tabular}{lcccc}
\hline \multicolumn{4}{c}{ mRNA level } \\
\cline { 2 - 5 } & Cortex & PVN & SON & Thalamus \\
\hline$\alpha 2$ & & & & \\
$\quad$ Control & $140 \pm 6$ & $152 \pm 18$ & $151 \pm 24$ & $129 \pm 7$ \\
Salt & $121 \pm 11$ & $141 \pm 13$ & $143 \pm 12$ & $123 \pm 7$ \\
$\alpha 3$ & & & & \\
Control & $833 \pm 84$ & $942 \pm 66$ & $757 \pm 151$ & $839 \pm 73$ \\
Salt & $866 \pm 71$ & $906 \pm 61$ & $703 \pm 136$ & $836 \pm 69$ \\
\hline
\end{tabular}

The mRNA levels, equivalent to nanoCuries per gram of tissue of ${ }^{14} \mathrm{C}$-labeled standards, are mean $\pm \mathrm{SD}$ values. None of the differences between salt-treated and control tissues is statistically significant.

expressed in $\mathrm{HeLa}$ cells shows a higher affinity for $\mathrm{Na}^{+}$than $\alpha 2$ or $\alpha 3$ expressed in the same cells. On the other hand, the isoform with a high ouabain affinity (presumably $\alpha 2$ and/or $\alpha 3$ ) in intact synaptosomes is reported to have a low affinity for $\mathrm{Na}^{+}$but is converted to a form with high $\mathrm{Na}^{+}$affinity when the synaptosomes are disrupted to synaptic plasma membranes (Brodsky and Guidotti, 1990). Because the measured $\mathrm{Na}^{+}$affinity may depend on the method used to isolate the enzyme, inferences regarding enzyme function in situ may be limited. Analysis of functional induction of mRNA expression in vivo is an alternative approach to investigate the role of specific isoforms in the brain.

The results of the present report show that stimulation of electrical activity in a population of cells expressing all three $\alpha$ isoforms of $\mathrm{Na}^{+}, \mathrm{K}^{+}$-ATPase in vivo induces expression specifically of the $\alpha 1$ isoform mRNA. Although there are many other ionic and endocrine effects of salt treatment, those changes would presumably affect all brain regions and did not appear to alter $\mathrm{Na}^{+}, \mathrm{K}^{+}$-ATPase $\alpha$ isoform expression in the brain. This specific induction of $\alpha 1 \mathrm{mRNA}$ in cells with increased electrical activity suggests that $\alpha 1$ may be the $\mathrm{Na}^{+}, \mathrm{K}^{+}$-ATPase catalytic subunit isoform responsible for pumping $\mathrm{Na}^{+}$that enters the cell through voltage-gated channels during electrical depolarization.

In a previous study, the amount of $\mathrm{Na}^{+}, \mathrm{K}^{+}$-ATPase, measured by binding of an ${ }^{125}$ I-labeled antibody against the enzyme, showed no change in cultured chick sensory neurons after $24 \mathrm{~h}$ of veratridine-mediated $\mathrm{Na}^{+}$influx (Tamkun and Fambrough, 1986). However, that study predated the identification of the three $\alpha$ isoforms and therefore did not investigate whether isoform-specific alterations were induced by depolarization. It is also possible that the duration of stimulation/depolarization may be an important variable.

Increased mRNA levels could result from increased transcription or decreased mRNA turnover. The experiments reported do not allow us to distinguish be- tween these two possibilities. Increased mRNA levels may not be reflected in corresponding increases in protein levels or in functional enzyme because it has been demonstrated that the insertion of functional enzyme into the membrane may depend in some circumstances on the coordinate regulation of synthesis of appropriate $\beta$ isoform subunits (Lescale-Matys et al., 1990; Taormino and Fambrough, 1990). In several different in vitro systems, however, the pump number is increased in response to increased demands for ion transport (Boardman et al., 1974; Wolitzky and Fambrough, 1986; Pressley, 1988).

The results of the present study, showing that in one population of neurons increased electrical activity is accompanied by increased levels of $\alpha 1 \mathrm{mRNA}$, suggest a link between depolarization and the $\alpha 1$ isoform of $\mathrm{Na}^{+}, \mathrm{K}^{+}$-ATPase. Studies of the ultrastructural localization of the different isoforms within neurons and the functional regulation of isoform expression in other neuronal systems in vivo and in vitro are currently underway in our laboratory.

Acknowledgment: This work was supported by grants from the Veterans Administration (to M. Mata and D. J. Fink), the National Institutes of Health (to D. J. Fink), and the Hartford Foundation (to M. Beaty). We acknowledge the statistical consultation of James Wan, Ph.D., of the University of Michigan Geriatrics Research and Training Center Statistical Core.

\section{REFERENCES}

Arnauld E., Dufy B., and Vincent J.-D. (1975) Hypothalamic supraoptic neurones: rates and patterns of action potential firing during water deprivation in the unanesthetized monkey. Brain Res. 100, 315-325.

Boardman L., Huett M., Lamb J. F., Newton J. P., and Polson J. M. (1974) Evidence for the genetic control of the sodium pump density in HeLa cells. $J$. Physiol. (Lond.) 241, 771-794.

Bowen J. W. and McDonough A. (1987) Pretranslational regulation of Na-K-ATPase in cultured canine kidney cells by low $\mathrm{K}^{+}$. Am. J. Physiol. 252, C179-C189.

Brimble M. J. and Dyball R. E. J. (1977) Characterization of the responses of oxytocin- and vasopressin-secreting neurones in the supraoptic nucleus to osmotic stimulation. J. Physiol. (Lond.) 271, 253-271.

Brodsky J. L. and Guidotti G. (1990) Sodium affinity of brain $(\mathrm{Na}, \mathrm{K})$-ATPase is dependent on isozyme and environment of the pump. Am. J. Physiol. 258, C803-C811.

Feige G., Leutert T., and De Pover A. (1989) Na,K-ATPase isozymes in rat tissues: differential sensitivities to sodium, vanadate and dihydroouabain, in Progress in Clinical and Biological Research, Vol. 268A: The Na,K-Pump, Part A: Molecular Aspects (Skou J. C., Norby J. G., and Maunsbach A. B., eds), pp. 377-384. Alan R. Liss, New York.

Filuk P. E., Miller M. A., Dorsa D. M., and Stahl W. L. (1989) Localization of messenger RNA encoding isoforms of the catalytic subunit of $\mathrm{Na}, \mathrm{K}-\mathrm{ATPase}$ in rat brain by in situ hybridization histochemistry. Neurosci. Res. Commun. 5, 155-162.

Goldshleger R., Sahak Y., and Karlish S. J. D. (1990) Electrogenic and electroneutral transport modes of renal $\mathrm{Na} / \mathrm{K}$ ATPase reconstituted into proteoliposomes. J. Membr. Biol. 113, 139154.

Hieber V., Siegel G. J., Fink D. J., Beaty M. W., and Mata M. (1991) Differential distribution of (Na,K)-ATPase alpha iso- 
forms in the central nervous system. Cell. Mol. Neurobiol. 11, 253-262.

Jewell E. A. and Lingrel J. B. (1991) Comparison of the substrate dependence properties of the rat $\mathrm{Na}, \mathrm{K}$-A TPase alpha 1 , alpha2, and alpha 3 isoforms expressed in HeLa cells. J. Biol. Chem. 266, 16925-16930.

Lescale-Matys L., Hensley C., Crnkovic-Markovic R., Putnam D., and McDonough A. (1990) Low $\mathrm{K}^{+}$increases Na,K-ATPase abundance in LLC-PK1/C1 4 cells by differentially increasing beta, and not alpha, subunit mRNA. J. Biol. Chem. 265, 17935-17940.

Lingrel J. B., Orlowski J., Shull M. M., and Price E. M. (1990) Molecular genetics of Na,K-ATPase. Prog. Nucleic Acid Res. 38, 37-89.

Mata M., Fink D. J., Gainer H., Smith C. B., Davidsen L., Savaki H., Schwartz W. J., and Sokoloff L. (1980) Activity-dependent energy metabolism in rat posterior pituitary primarily reflects sodium pump activity. J. Neurochem. 34, 213-215.

Mata M., Siegel G. J., Hieber V., Beaty M. W., and Fink D. J. (1991) Differential distribution of (Na,K)-ATPase alpha isoforms in the peripheral nervous system. Brain Res. 546, 47-54.

McGrail K. M. and Sweadner K. J. (1986) Immunofluorescent localization of two different $\mathrm{Na}, \mathrm{K}-\mathrm{ATPases}$ in the rat retina and in identified dissociated retinal cells. $J$. Neurosci. 6, 1272 1283.

McGrail K. M., Phillips J. M., and Sweadner K. J. (1991) Immunofluorescent localization of three $\mathrm{Na}, \mathrm{K}-\mathrm{ATPase}$ isozymes in the rat central nervous system: both neurons and glia can express more than one Na,K-ATPase. J. Neurosci. 11, 381-391.

Pollack L. R., Tate E. H., and Cook J. S. (1981) Turnover and regulation of Na-K-ATPase in HeLa cells. Am. J. Physiol. 241, C173-C183.

Poulain D. A., Wakerley J. B., and Dyball R. E. J. (1977) Electrophysiological differentiation of oxytocin and vasopressin-secreting neurones. Proc. R. Soc. Lond. [Biol.] 196, 367-384.

Pressley T. A. (1988) Ion concentration-dependent regulation of Na,K-pump abundance. J. Membr. Biol. 105, 187-195.

Pressley T. A., Ismail-Beigi F., Gick G. G., and Edelman I. S. (1988) Increased abundance of Na-K-ATPase mRNAs in response to low external K. Am. J. Physiol. 255, C252-C260.

Ratkowski R. F., Gadsby D. C., and De Weer P. (1989) Stoichiometry and voltage dependence of the sodium pump in voltageclamped, internally dialyzed squid giant axon. J. Gen. Physiol. 93, 903-941.

Rowe P. M., Link W. T., Osborn C. P., Gainer H., and Albers R. W.
(1991) Distribution of $\mathrm{Na}^{+}, \mathrm{K}^{+}-\mathrm{ATPase} \alpha$-subunit isoforms in rat pituitary. J. Neurochem. 57, 1088-1090.

Schwartz W. J., Smith C. B., Davidsen L., Savaki H., Sokoloff L., Mata M., Fink D. J., and Gainer H. (1979) Metabolic mapping of functional activity in the hypothalamo-neurohypophysial system of the rat. Science 205, 723-725.

Skou J. C. (1962) Preparation from mammalian brain and kidney of the enzyme system involved in active transport of $\mathrm{Na}$ and $\mathrm{K}$. Biochim. Biophys. Acta 58, 314-325.

Specht S. C. and Sweadner K. J. (1984) Two different $\mathrm{Na}, \mathrm{K}-\mathrm{ATPases}$ in the optic nerve: cells of origin and axonal transport. Proc. Natl. Acad. Sci. USA 81, 1234-1238.

Swann A. C. (1991) Brain Na,K-ATPase regulation in vivo: reduction in activity and response to sodium by intracerebroventricular tetrodotoxin. Brain Res. 543, 251-255.

Sweadner K. J. (1985) Enzymatic properties of separated isozymes of the Na,K-ATPase substrate affinities, kinetic cooperativity, and ion transport stoichiometry. J. Biol. Chem. 260, 1150811513.

Sweadner K. J. (1989) Isozymes of the Na/K-ATPase. Biochim Biophys. Acta 988, 185-220.

Tamkun M. M. and Fambrough D. M. (1986) The ( $\left.\mathrm{Na}^{+}-\mathrm{K}^{+}\right)$-ATPase of chick sensory neurons: studies on biosynthesis and intracellular transport. J. Biol. Chem. 261, 1009-1019.

Taormino J. P. and Fambrough D. M. (1990) Pre-translational regulation of the $\left(\mathrm{Na}^{+}, \mathrm{K}^{+}\right)$-ATPase in response to demand for ion transport in cultured chicken skeletal muscle. J. Biol. Chem. $265,4116-4123$

Urayama O. and Nakao M. (1979) Organ specificity of rat sodium and potassium activated adenosine triphosphatase. J. Biochem. (Tokyo) 86, 1371-1381.

Urayama O. and Sweadner K. J. (1988) Ouabain sensitivity of the alpha 3 isozyme of rat Na,K-ATPase. Biochem. Biophys. Res. Commun. 156, 796-800.

Watts A. G., Sanchez-Watts G., Emanuel J. R., and Levenson R. (1991) Cell-specific expression of mRNAs encoding Na,K-ATPase alpha- and beta-subunit isoforms within the rat central nervous system. Proc. Natl. Acad. Sci. USA 88, 74257429.

Wilkinson L. (1986) SYSTAT: The System for Statistics. SYSTAT, Evanston, Illinois.

Wolitzky B. A. and Fambrough D. M. (1986) Regulation of the (Na,K)-ATPase in cultured chick skeletal muscle: modulation of expression by the demand for ion transport. J. Biol. Chem. 261, 9990-9999. 